\title{
Geotechnical Behavior of Pliocene Sedimentary Rocks Exposed along Qena-Safaga Road at Qena region, Egypt
}

\author{
Hesham A. H. Ismaiel ${ }^{1, *}$, Afaf A. Makhloof ${ }^{2}$, Atif A. Mahmoud ${ }^{2}$, Ahmed A. Galal ${ }^{3}$ \\ ${ }^{1}$ Geology Department, Faculty of Science, South Valley University, Qena, 83523, Egy pt \\ ${ }^{2}$ Civil En gineering Department, Faculty of Engineering, Minia University, Minia, 12345, Egypt \\ ${ }^{3}$ Mining En gineering Department, Faculty of Engineering, Al-Azhar University, Qena, 83523, Egy pt
}

\begin{abstract}
Geotechnical properties of Pliocene sedimentary rocks (Durri Formation) exposed along Qena-Safaga road were investigated to evaluate their geotechnical behaviour. The purpose of this research was to interpret a real reason of cracks occurring in the asphalt layer and in the area around the road and to suggest the suitable treatment of theses cracks. Durri Formation lies under the asphalt layer as sub-grade and exposed along the road at the study area. Mineralogical analysis of the studied samples showed that the Pliocene sedimentary rocks were mainly composed of calcite and clay minerals. Petrographical investigation showed that the studied Pliocene sedimentary rocks of Durri Formation at the studied area were mainly composed of five sedimentary microfacieses including mudstone, marlstone, marly, dolo mitic and detrital limestone. Unconfined compressive strength of the studied sedimentary microfacieses was ranging from 155.92 to $291.92 \mathrm{~kg} / \mathrm{cm}^{2}$. Mudstone and detrital limestone mic rofacieses had the lowest values (155.92 to $\left.197.50 \mathrm{~kg} / \mathrm{cm}^{2}\right)$; in contrast, marlstone, marly limestone and dolomit ic limestone micro facieses had the highest values $\left(218.29\right.$ to $\left.291.92 \mathrm{~kg} / \mathrm{cm}^{2}\right)$. Swelling pressure value of the mudstone microfacies was $6.50 \mathrm{~kg} / \mathrm{cm}^{2}$ and the swelling pressure of the marly limestone microfacieses was ranging from 0.44 to $2.10 \mathrm{~kg} / \mathrm{cm}^{2}$. Marlstone microfacies had the highest swelling pressure value $\left(16.00 \mathrm{~kg} / \mathrm{cm}^{2}\right)$. In contrast, dolomitic and detrital limestone microfacieses had not swelling pressure. Retained percent of the slaking durability test of the studied sedimentary mic rofacieses was ranging from 88.70 to $94.60 \%$ having mediu $m$ to high durability according to slake durability classification of Gamble, except one high expansive marlstone microfacies had low retained percent (58.00\%) and was described as low durability mic rofacies. Expansive sedimentary rock microfacieses of Durri Formation including mudstone, marlstone and marly limestone mic rofacieses which represent the sub-grade of the road were swollen due to water coming from the damaged old water pipe that runs parallel to the road and that led to a heave of both the road and the damaged old water pipe. The heave of the old water pipe led to an increase of the damage and the amount of the water coming from this pipe. In addition, drying the saturated Pliocene sedimentary microfacieses due to solar radiation led to a formation of large scale mud cracks having triple junction, polygonal and randomly oriented forms. The se cracks occurs on the asphalt layer and in the area around the road at the study area. Grouting of the cracks using cement and chemical stabilization of the expansive sub-grade sedimentary mic rofacies utilizing lime were suggested to treat these cracks and to reduce the swelling pressure respectively. In addition, monitoring system of the cracks using total station was suggested to evaluate the displace ment of these cracks and to determine the relationship between cracks orig in and recent tectonic movement at the study area.
\end{abstract}

Keywords Geotechnical and Petrographical Properties, Durri Formation, Swelling Pressure, Slake Durability and Cracks

\section{Introduction}

Geotechnical properties of the rocks play an important role on an evaluation of their geotechnical behavior which reflected as a result of their physical and geological properties. In this work, geotechnical properties of Durri Formation exposed along Qena-Safaga road were investigated to understand their geotechnical behaviour.

* Corresponding author:

heshahmed@y ahoo.com (Hesham A.H. Ismaiel)

Published online at http://journal.sapub.org/mining

Copyright @ 2012 Scientific \& Academic Publishing. All Rights Reserved

\subsection{Pre vious Works}

Many detailed geological and geophysical studies had been carried out in the present study area like[1],[2],[3],[4],[5],[6],[7],[8],[9],[10],[11],[12],[13] and others. Only one engineering geophysical investigation was carried out at new Qena city by [14]. Another geotechnical research was carried out by[15] at Luoxur city. In addition, reference[16] showed the geotechnical properties of limestone in Egypt. There are no previous geotechnical and engineering geological investigations at the study area. Thus, 
the study area needs to be geotechnicaly investigated in details.

\subsection{Scope of the Present Work}

The present study dealt with an investigation of the geotechnical properties of Pliocene sedimentary rocks (Durri Formation) exposed along Qena-Safaga road (between $\mathrm{km}$ 18 to $\mathrm{km} 31$, from Qena to Safaga) at Qena region to evaluate their geotechnical behaviour. One of the most important aims of this work was to find real reas ons of cracks occurring in the asphalt layer and in the area around the road at the study area and to suggest the suitable geotechnical treatment of theses cracks.

\section{Geographical and Geological Setting}

The study area lies across Qena-Safaga road at a distance between $\mathrm{km} 18$ and $\mathrm{km} 31$ east of Qena city, it lies between $26^{\circ} 16^{\prime} 59^{\prime \prime} \& 26^{\circ} 20^{\prime} 9^{\prime \prime}$ north and $32^{\circ} 48^{\prime} 17^{\prime \prime} \& 32^{\circ} 55^{\prime} 12^{\prime \prime}$ east. It covers about $6885811 \mathrm{~m}^{2}$. The study area is deformed by many cracks. The study area is divided into nine zones (from A to I) based on an occurrence and a distribution of these cracks (Figure.1).

The study area consists geologically of a relatively low-ly ing conspicuous plain covered by Plio-Pleistocene sediments overlying Upper Cretaceous-Lower Tertiary (Eocene) strata[17]. Qena-Safaga shear zone has long tectonic history since Precambrian times and shows dextral sense of shear proved by the remarkable displacement of the basement rocks, particu larly near $22 \mathrm{~km}$ fro $\mathrm{m}$ Safaga coastal city. Dextral shear criteria are also recorded some $2 \mathrm{~km}$ to the south of the asphalted road along Wadi Bola $(20 \mathrm{~km}$ from Safaga)[10]. Some studies believed that Qena-Safaga shear zone is an active tectonic zone till the present time. The distribution of the Plio-Pleistocene sediments at the studied area was illustrated in the geological map (Figure. 2). Quaternary sediments (Ple istocene and Recent) include wadi deposits, fanconglomerate and pre-nile deposits. Pliocene deposits are lacustrine and include Durri Formation. The sub-grade of Qena-Safaga road at the present study area consists of Pliocene sediments (Durri Formation).

\section{Description of the Observed Damage}

A roadway section consists of a complete pavement system[18] (Figure. 3). The sub-grade refers to the in situ soils (or rocks) on which the stresses from the overlying roadway will be distributed. The sub-base or sub-base course and the base or base course materials are stress distributing layer overlying sub-grade layer and underlying of the pavement layer. The pavement structure consists of a relatively thin wearing surface constructed over a base course and a sub-base course, which rests upon an in situ sub-grade. The wearing surface is primarily as phalt/concrete.

The observed cracks are distributes in nine zones at the study area. The cracks have different forms and extensions (Figures 4 and 5). The cracks forms are triple junction and polygonal. Some observed cracks have randomly oriented forms. So me cracks occur in both asphalt layer and adjacent area, other cracks occur only in the asphalt layer or adjacent area. The width of the observed cracks is ranging from 1 to $50 \mathrm{~cm}$. the width is increasing upwards. The extension (length) is ranging from 1 to $100 \mathrm{~m}$. The depth of the observed cracks (from the field observations) is approximately ranging from few to ten meters.

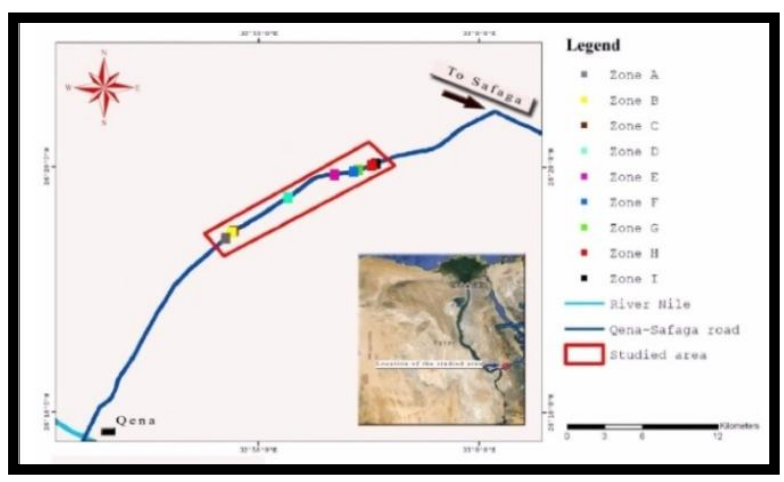

Figure 1. Location map of the studied area

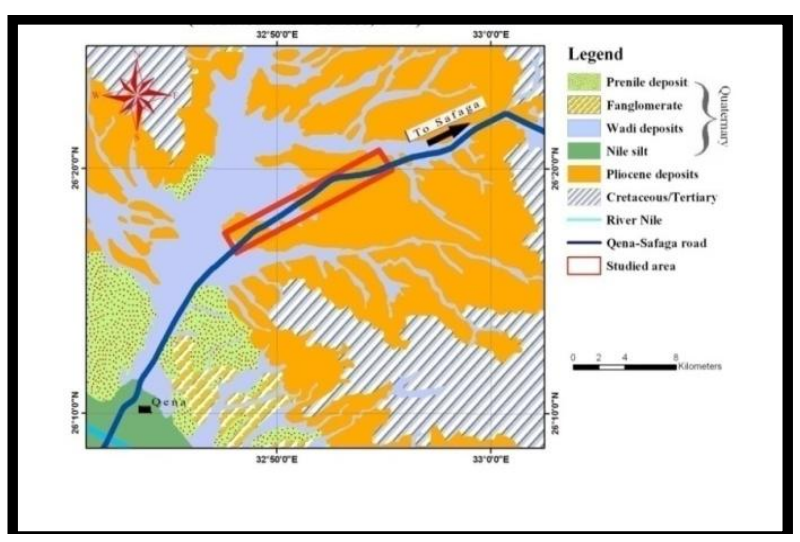

Figure 2. Geological map of the studied area modified after Conoco (1986)

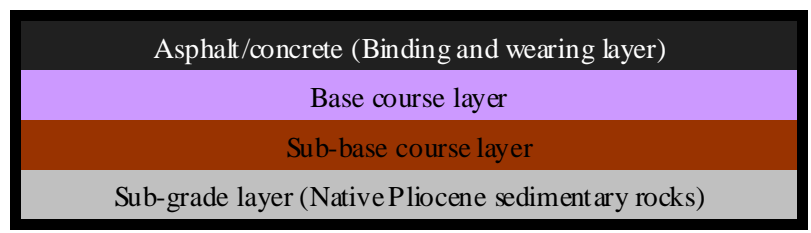

Figure 3. A typical flexible pavement structure

\section{Materials and Methods}

\subsection{Materials}

112 samples (40 disturbed samples and 72 undisturbed samples) represented eight different sedimentary microfacieses of Durri Formation and distributed along the road at the studied zones were collected. They were subjected to different geological and geotechnical 
investigations to achieve the scopes of the present work. The lithology and the thickness of the Pliocene sedimentary rocks (Durri Formation) at type locality (Gabel El-Durri, east of Higaza, South east of Qena) is a lacustrine white limestone and marly limestone, with shale, sandstone and conglomerates lenses and tongues. It comprises a pronounced one meter thick bed of fresh-water algal balls and oncolites (maximum $20 \mathrm{~cm}$ in diameter). Globular weathering gives a false impression of the occurrence of stromatolites. Local syn-sedimentary slumping is observed. Thickness is $30 \mathrm{~m}$ thinning out towards the Nile valley[19].

\subsection{Methods}

Five geotechnical tests including specific gravity, Sch midt hammer, unconfined comp res sive strength (according to [20]), swelling pressure (using Oedometer test and accodding to[21] with seven stresses levels were applied including $0.25,0.50$, $1.00,2.00,4.00,8.00$ and $16.00 \mathrm{~kg} / \mathrm{cm}^{2}$ ) and slaking durability (according to[22]) were conducted on the studied sedimentary microfacieses of Durri Formation after two 10-minute cycles. Petrographical description of the studied sedimentary rocks using polarized light microscope with digital camera was conducted to understand a texture and a mineral co mposition of the studied sedimentary microfacies es. Chemical (x-ray fluorescence, XRF) and mineralogical (x-ray diffraction, XRD) analysis of the investigated sedimentary microfacieses were also carried out.

\section{Results}

\subsection{Chemical and Mineralogical Analysis Results}

Table (1) illustrated the chemical composition of the studied Durri Formation rock microfacieses distributed at the study area. The results showed that the studied Durri Formation was mainly composed of calcium, silica, magnesium and aluminum. It contained sodium, iron and others as minor components. Mineralogical analys is results showed that the Durri Formation at the study area was mainly composed of calcite, clay minerals (especially illite as major component and montmorillonite as minor component), quartz and dolo mite.

\subsection{Petrographical Study Results}

Petrographical studies were carried out on eight samples collected from Durri Formation according to the difference of facieses in the field and distributed at the study area (Figure 6). Eight thin sections were prepared and examined using polarized light microscope. The petrographical investigation showed that the investigated samples represent five main different microfaces of Durri Formation. These microfacies were mudstone, marlstone, marly limestone, dolomitic detrital limestone and detraital limestone. Figure (7) showed photomicrographs of the studied sedimentary microfacieses of Durri Formation illustrating their texture and their mineral composition. Petrographical description of these studied microfacieses were as follows:
Mudstone microfacies was very fine to mediu m grained. It was recorded at the upper part of Du rri Formation. The rock of this microfacies was green to green ish grey color. It consisted essentially of calcite, clay and quartz. The rock was composed of few skeletal debris, some reworked planktonic and benthonic foraminifera. These components were embedded in micrite matrix which partly stained by iron oxides. The microfacies was characterized by bioclastic packstone texture, see Figure (7.a).

Marlstone microfacies was medium grained. It was recorded at the upper part of Durri Formation. The rock of this microfacies was greenish grey in color. It was cracked, ferruginous and containing shell fragments. The rock consisted essentially of calcite, clay and quartz. The rock contained approximately equal amount of calc ite and clay minerals. The components were embedded in mic ritic matrix. This microfacies is bioclastic packstone texture, see Figure (7.e)

Marly limestone microfacies was fine to mediu m grained. It was recorded at the upper part of Durri Formation. The rock of this microfacies was grey in color. It is hard, cracked, ferruginous and containing shell fragments. The rock consisted essentially of calcite, clay and quartz. Detraital calcite and other grains were embedded in micrite with partially sparite. This microfacies was lithoclastic/bioclastic and wackstone/packstone. Investigated specimen no.1 was fine and wackstone, specimen no. 2 was medium and wackstone and specimen no.3 was very fine and wackstone, see Figures (7.b, 7.c and 7.d).

Dolomitic detrital limestone microfacies was very fine grained. It was recorded at uppermost part of Durri Formation. The rock of this microfacies was yellowish grey in color. It was very hard, ferruginous and partially dolomitizied and silicified. The rock was essentially composed of calcite, clay, quartz and dolomite. Very fine calcite and quartz grains were embedded in micritic groundmass. This microfacies was characterized by wacks tone texture, see Figure (7.f).

Detraital limes tone micro facies was fine to coarse grained. It was recorded at the uppermost part of Durri Formation. The rock of this microfacies was whitish to yellowish grey in color. It was ferruginous and consisted essentially of calcite and quartz. The rock was co mposed of fine to coarse detraital quartz grains. These components were embedded in micrit matrix with partially sparite. This microfacies was characterized by lithoclastic texture. An investigated specimen no.1 contained silt size detraital quartz grains and specimen no. 2 contained sand size detraital quartz grains, see Figures (7.g and 7.h).

\subsection{Geotechnical Results}

\subsubsection{Specific Gravity Test Results}

The results showed that the investigated samples of the rocks had slightly different values of specific gravity according to their mineral composition. Specific gravity values of the studied sedimentary rock microfacieses were ranging from 1.96 to $2.18 \mathrm{~g} / \mathrm{cm}^{3}$, see Table (2). 


\subsubsection{Sch midt Hammer Test Results}

Unconfined compressive strength was calculated using schmidt hammer number and specific gravity of each rock microfacies. Dolomitic detrital limestone, marlstone and marly limestone microfacies had higher values of Schmidt number and strength; in contrast, detraital limestone microfacieses had lower values. Unconfined compressive strength value, using schmidt hammer nu mber, of the studied microfacieses were ranging from 274.00 to $461.07 \mathrm{~kg} / \mathrm{cm}^{2}$, see Table (2). Dolomitic detraital limestone microfacies had the highest value $\left(461.07 \mathrm{~kg} / \mathrm{cm}^{2}\right)$.

\subsubsection{Unconfined Compressive Strength Test Results}

Unconfined compressive strength values (according to[20]) of the studied sedimentary microfacieses of Durri Formation were ranging from 155.32 to $291.92 \mathrm{~kg} / \mathrm{cm}^{2}$, see Table (2). Dolo mitic detrital, marlstone and marly limestone had higher values (218.29 to $291.92 \mathrm{~kg} / \mathrm{cm}^{2}$ ) compared to detraital limestone and mudstone microfacieses which had lower values (155.92 to $\left.197.50 \mathrm{~kg} / \mathrm{cm}^{2}\right)$, see Table (2).

\subsubsection{Swelling Pressure (Oedometer) Test Results}

Results of swelling pressure test using oedometer instrument (according to[21]) showed that the swelling pressure values of the studied microfacieses including mudstone, marlstone and marly limestone were ranging fro $\mathrm{m}$ 0.44 to $16.00 \mathrm{~kg} / \mathrm{cm}^{2}$. Marlstone microfacies had the highest value $\left(16.00 \mathrm{~kg} / \mathrm{cm}^{2}\right)$. In contrast, dolomitic and detrital limestone microfacieses had not swelling pressure, see Table (2).

\subsubsection{Slake Durability Test Results}

Durability of rocks is fundamentally important for all applications. Changes in the properties of rocks are produced by slaking (decrepitating), exfoliation, hydration, solution, abrasion and other processes. Slake durability apparatus, after[22], was used to determine the durability of the studied sedimentary rocks. The results showed that the studied sedimentary rock microfacieses had retained percent ranging from 88.70 to $94.60 \%$. They were described as medium to high durability after Gamble's classification. One sample (marlstone microfacies) had retained percent equal to $58.00 \%$ and was described as low durability, see Table (2).

Table 1. Chemical composition of Durri Formation

\begin{tabular}{|c|c|c|c|c|c|c|c|c|c|c|c|c|}
\hline $\begin{array}{c}\text { Chemical } \\
\text { Oxides }\end{array}$ & $\mathrm{S}_{\mathrm{i}} \mathrm{O}_{2}$ & $\mathrm{~T}_{\mathrm{i}} \mathrm{O}_{2}$ & $\mathrm{Al}_{2} \mathrm{O}_{3}$ & $\mathrm{Fe}_{2} \mathrm{O}_{3}$ & $\mathrm{MnO}$ & $\mathrm{MgO}$ & $\mathrm{CaO}$ & $\mathrm{Na}_{2} \mathrm{O}$ & $\mathrm{K}_{2} \mathrm{O}$ & $\mathrm{P}_{2} \mathrm{O}_{5}$ & $\mathrm{SO}_{3}$ & $\mathrm{LOI}$ \\
\hline $\begin{array}{c}\text { Percent } \\
(\%)\end{array}$ & 25.14 & 0.13 & 4.22 & 1.06 & 0.01 & 6.72 & 29.05 & 1.10 & 0.40 & 0.33 & 0.44 & 30.96 \\
\hline
\end{tabular}

LOI= Loss of ignition, at $1000^{\circ} \mathrm{C}$.

Table 2. Geotechnical properties of the sedimentary microfacieses of Durri Formation at the study area

\begin{tabular}{|c|c|c|c|c|c|c|}
\hline $\begin{array}{r}\text { Geotechnical } \\
\text { properties }\end{array}$ & Specific & $\begin{array}{c}\text { qu-value } \\
\text { using Schmidt }\end{array}$ & $\begin{array}{l}\text { qu-value } \\
\text { using }\end{array}$ & $\begin{array}{l}\text { Swelling } \\
\text { Pressure }\end{array}$ & \multicolumn{2}{|c|}{ Slake durability } \\
\hline Microfacies type & $\begin{array}{l}\text { Gravity } \\
\left(\mathrm{g} / \mathrm{cm}^{3}\right)\end{array}$ & $\begin{array}{c}\text { hammer } \\
\text { number } \\
\left(\mathrm{kg} / \mathrm{cm}^{2}\right)\end{array}$ & $\begin{array}{c}\text { laboratory test } \\
\left(\mathrm{kg} / \mathrm{cm}^{2}\right) \\
\text { (DIN } 18 \text { 136) }\end{array}$ & $\begin{array}{l}\text { Using } \\
\text { Oedometer } \\
\left(\mathrm{kg} / \mathrm{cm}^{2}\right) \\
\end{array}$ & $\begin{array}{c}\text { Retained } \\
(\%)\end{array}$ & Quality \\
\hline Mudstone & 2.01 & 353.16 & 197.50 & 6.50 & 90.80 & \multirow{4}{*}{ 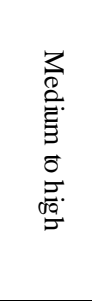 } \\
\hline $\begin{array}{l}\text { Marly limestone } \\
\text { (1) }\end{array}$ & 1.98 & 412.02 & 270.27 & 0.44 & 94.00 & \\
\hline $\begin{array}{l}\text { Marly limestone } \\
\text { (2) }\end{array}$ & 1.96 & 353.10 & 218.29 & 2.10 & 93.60 & \\
\hline $\begin{array}{l}\text { Marly limestone } \\
\text { (3) }\end{array}$ & 2.01 & 382.59 & 270.00 & 1.47 & 91.80 & \\
\hline Marlstone & 2.11 & 362.97 & 239.08 & 16.00 & 58.00 & low \\
\hline $\begin{array}{c}\text { Dolomitic } \\
\text { detrital } \\
\text { limestone }\end{array}$ & 2.18 & 461.07 & 291.92 & - & 94.60 & \multirow{3}{*}{ 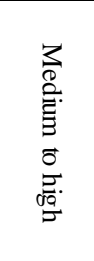 } \\
\hline $\begin{array}{c}\text { Detrital } \\
\text { limestone (1) }\end{array}$ & 1.97 & 274.00 & 155.92 & - & 93.40 & \\
\hline $\begin{array}{c}\text { Detrital } \\
\text { limestone (2) }\end{array}$ & 2.02 & 274.68 & 166.32 & - & 88.70 & \\
\hline
\end{tabular}

$\mathrm{qu}=$ Unconfined compressive strength . 

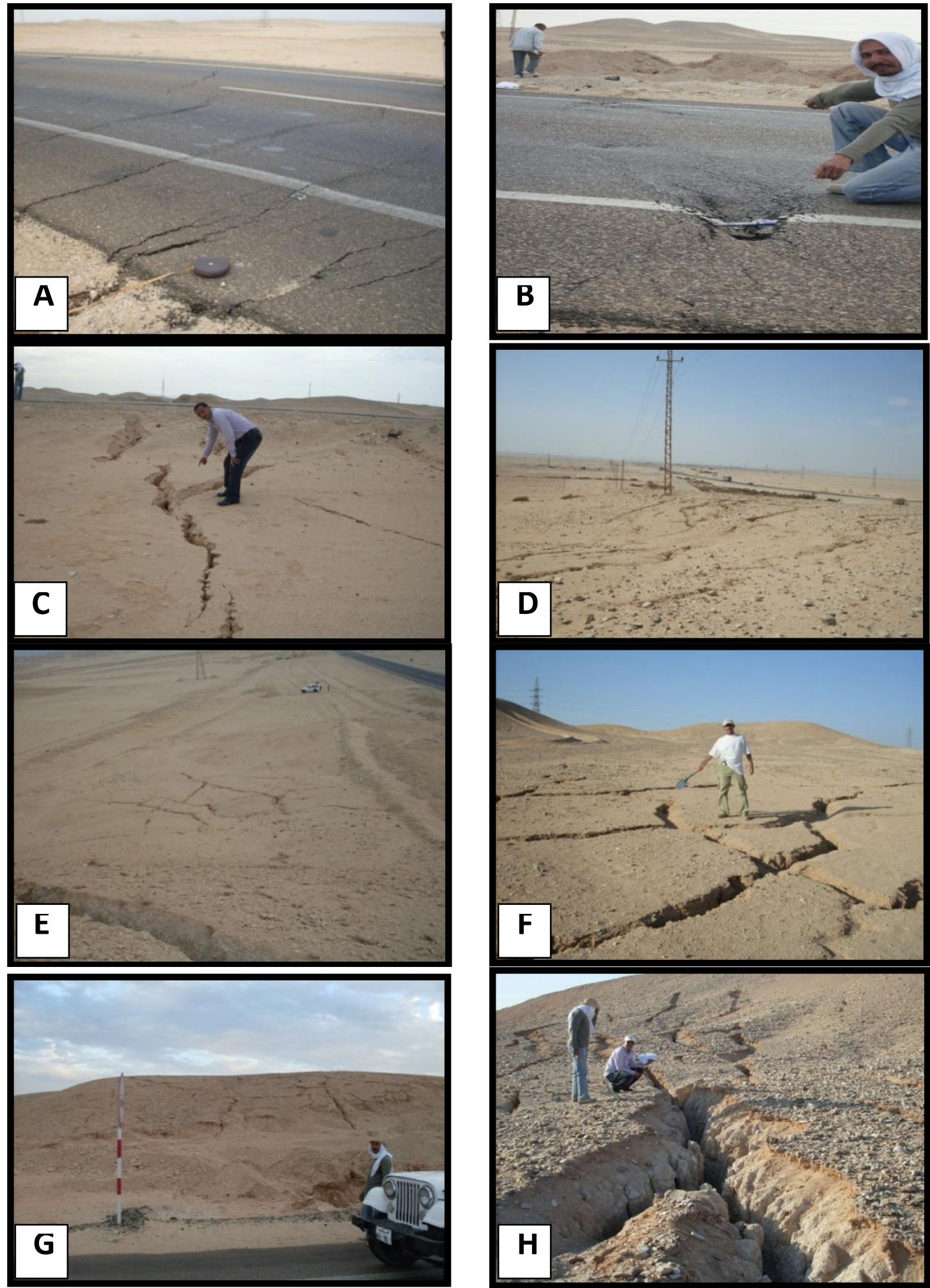

Figure 4. Different forms of cracks including triple junction, polygon and randomly oriented cracks at the study area. A and B) Cracks across the asphalt layer at zone d. C) Triple junction cracks lie near the asphalt layer at zone d. D) Polygon and randomly oriented cracks at zone a. E) Polygon cracks at zone d. F) Polygon cracks at zone f. G) Polygon cracks on the top of Pliocene terraces at zone f. H) Large triple junction crack at zone d 

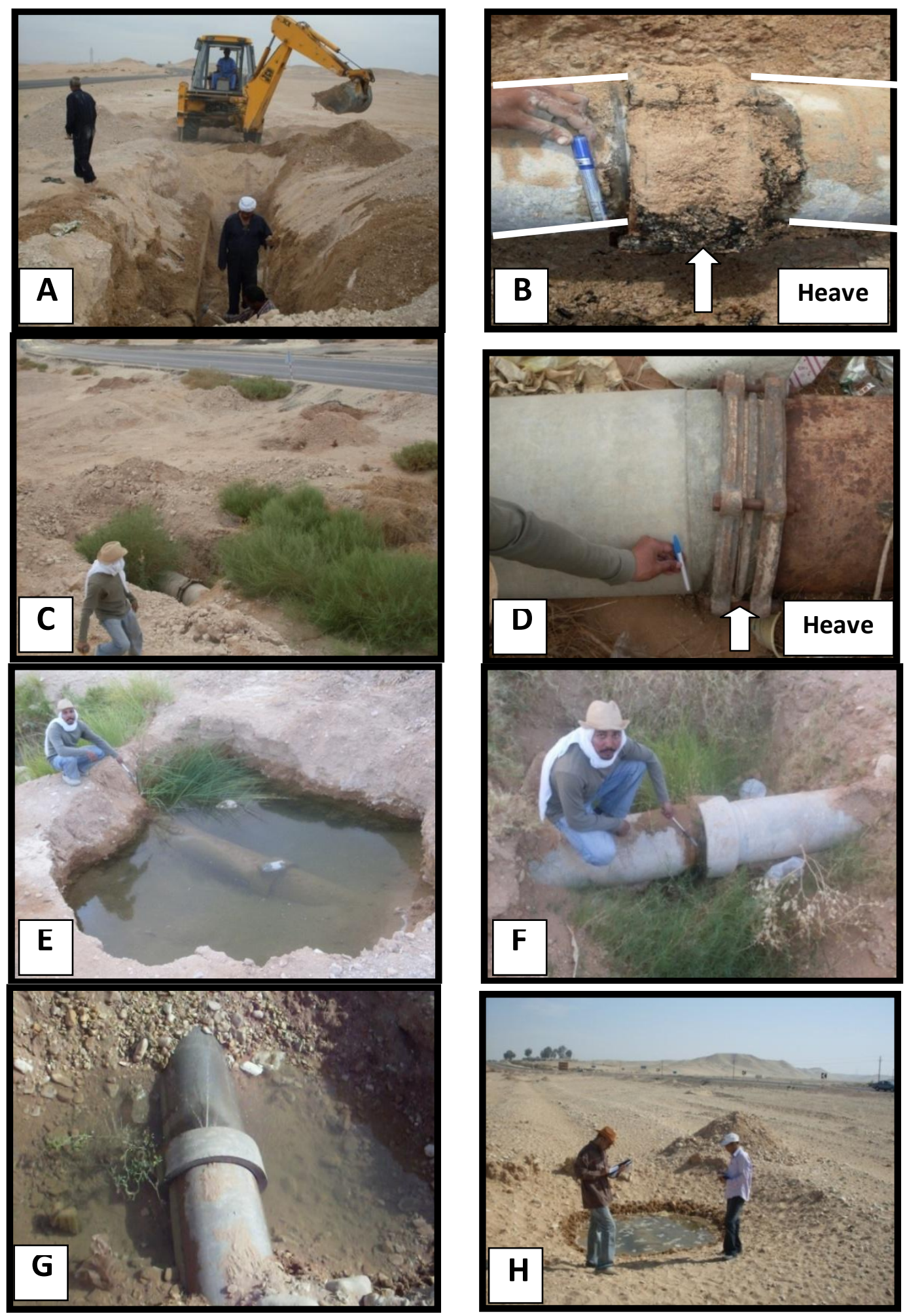

Figure 5. Damage of a water pipe at different studied zones. A and B) Damage of water pipe at zone d illustrated a heave of the old water pipe due to swelling of Pliocene sub-grade (mudstone, marlstone and marly limestone). C) Damage at zone f. D) Heave of the old water pipe due to swelling at zone e. $\mathrm{E}$ and F) Damages at zone i. G and H) Damages at zone h 

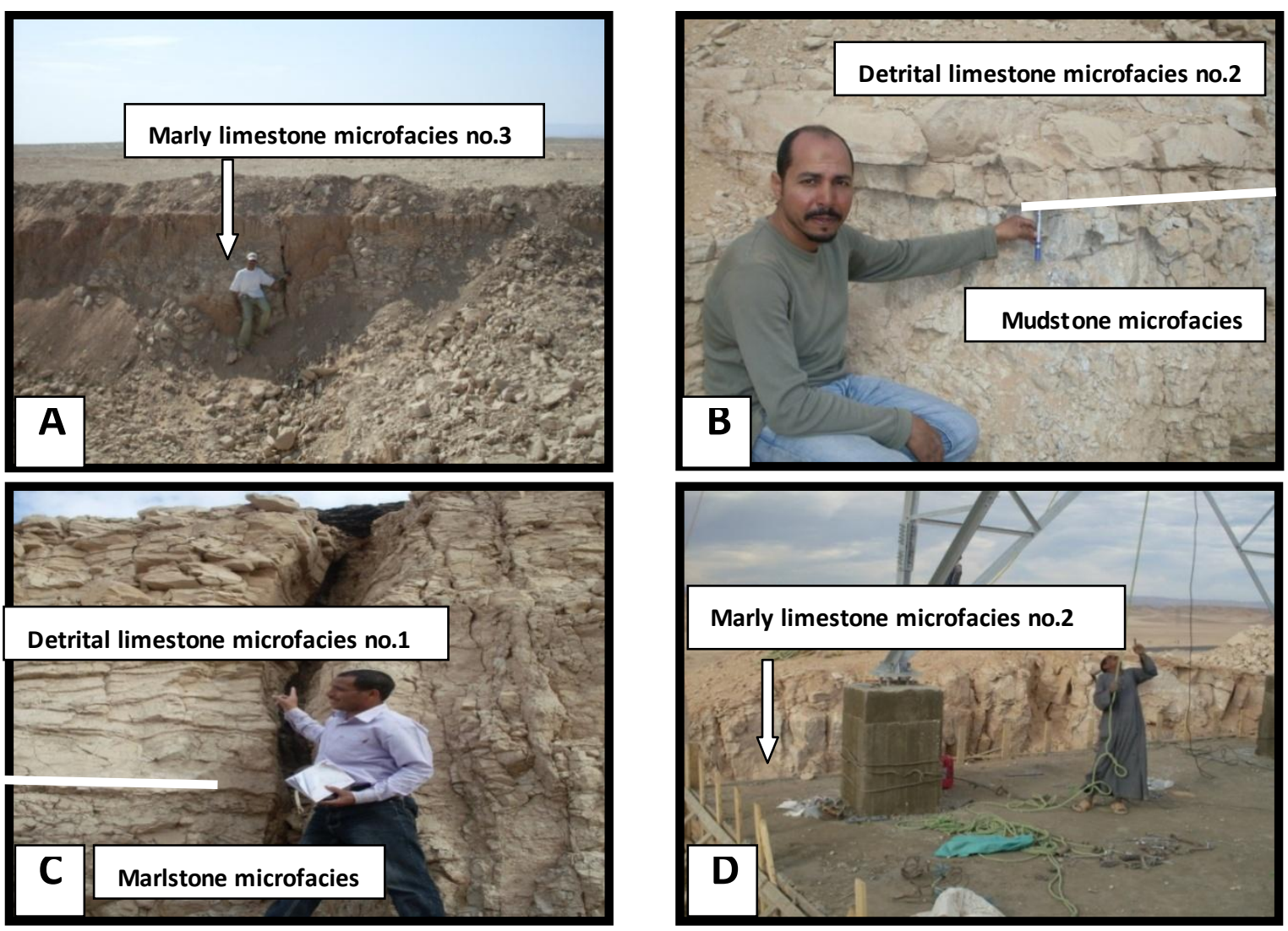

Figure 6. Different sedimentary microfacieses of Durri Formation exposed at the studied area. A) Marly limestone microfacies no.3 exposed at zone d, B) Mudst one and detrital limestone microfacies no.2 at zone d, C) Detrital limestone microfacies no.1 and marlstonemicrofacies at zone d, D) Marly limest one microfacies no.2 at zone $\mathrm{f}$

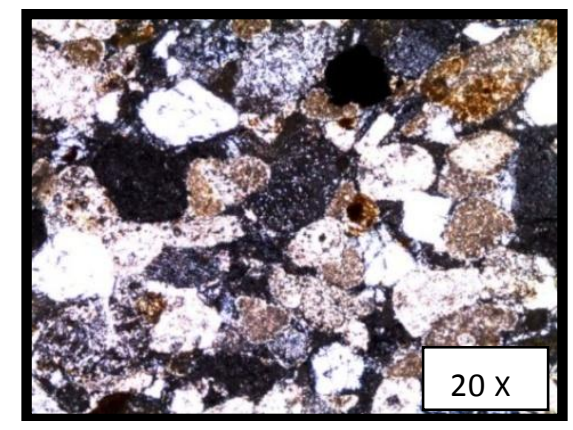

(a) Mudstone microfacies

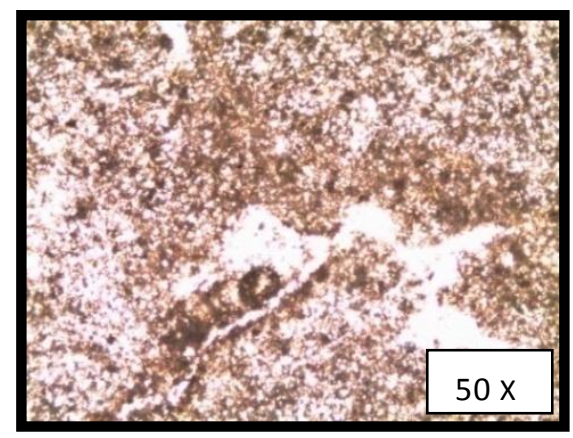

(b) Marly limest one microfacies (no.1)

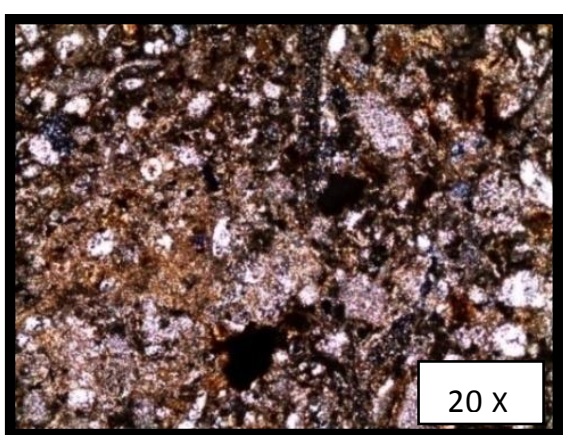

(c) Marly limestone microfacies (no.2)

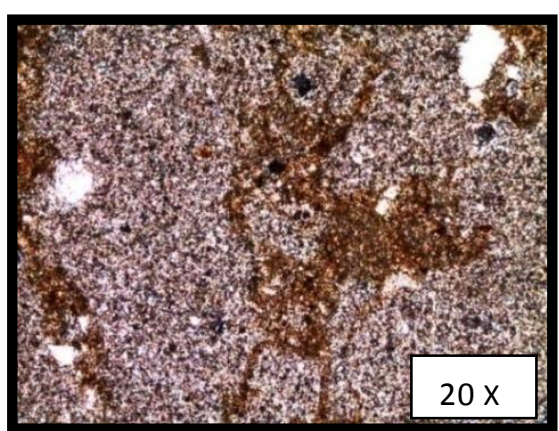

(d) Marly limestone microfacies (no.3) 


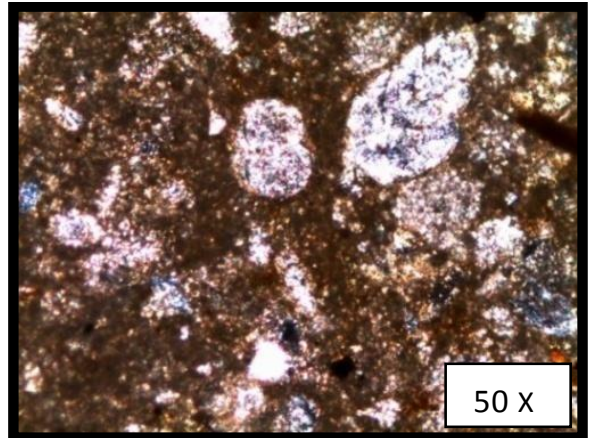

(e) Marlstone microfacies

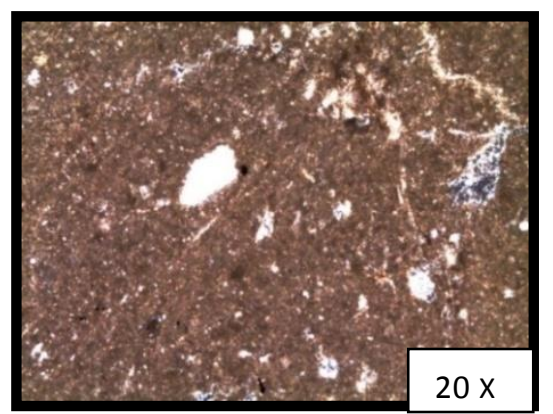

(f) Dolomitic detrital limestone microfacies

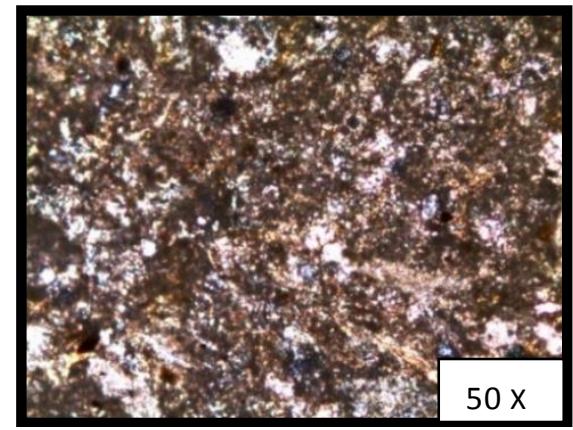

(g) Detraital (silty) limestone (no.1)

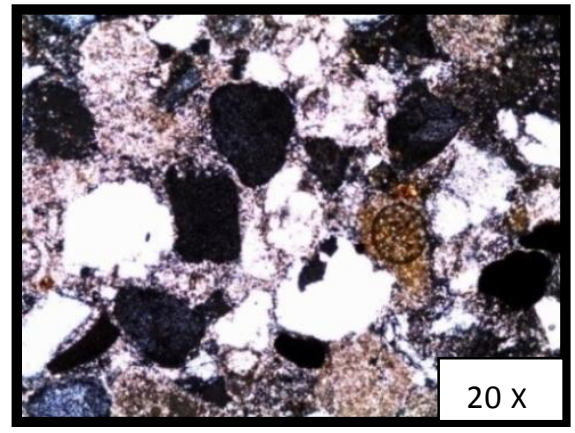

(h) Detraital (sandy) limest one (no.2)

Figure 7. Photomicrographs of the studied microfacieses (from a to $h$ )

\section{Conclusions and Recommendations}

\subsection{Conclusions}

Analysis and interpretation of the laboratory results and the field observations led to the following findings:

1- The chemical analysis of the studied Pliocene sedimentary microfacieses showed that the Durri Formation was mainly composed of calcium, silica, magnesium and aluminum. It contained sodium, iron and others as minor components. Mineralogical analysis results showed that the Durri Formation at the study area was mainly composed of calcite, clay minerals (especially illite as major component and montmorillonite as minor component), quartz and dolomite.

2- The petrographical investigation showed that the examined sedimentary rock specimens represent five main different microfaces of Durri Formation. These microfacies were mudstone, marlstone, marly limestone, dolomitic detrital limestone and detraital limestone.

3- The investigated rocks samples had slightly different specific gravity values according to their mineral composition. Specific gravity values of the studied sedimentary rock microfacieses were ranging from 1.96 to $2.18 \mathrm{~g} / \mathrm{cm} 3$. Dolomitic detrital limestone, marlstone and marly limestone microfacies had higher values of Schmidt number and strength; in contrast, detraital limestone microfacieses had lower values. Unconfined compressive strength value, using schmidt hammer nu mber, of the studied microfacieses were ranging from 274.00 to $461.07 \mathrm{~kg} / \mathrm{cm} 2$. Dolomitic detraital limestone microfacies had the highest value $(461.07 \mathrm{~kg} / \mathrm{cm} 2)$. Unconfined compressive strength values (according to[20]) of the studied sedimentary microfacieses of Durri Formation were ranging from 155.32 to $291.92 \mathrm{~kg} / \mathrm{cm} 2$. Dolo mitic detrital limestone, marlstone and marly limestone had higher values (218.29 to $291.92 \mathrm{~kg} / \mathrm{cm} 2$ ) compared to detraital limestone and mudstone microfacieses which had lower values (155.92 to $197.50 \mathrm{~kg} / \mathrm{cm} 2)$. The swelling pressure values of the studied microfacieses including mudstone, marlstone and marly limestone microfacieses were ranging from 0.44 to $16,00 \mathrm{~kg} / \mathrm{cm} 2$. Marlstone and mudstone microfacieses had the highest values $(16.00$ and $6.50 \mathrm{~kg} / \mathrm{cm} 2$ respectively). In contrast, dolomitic and detrital limestone microfacieses had not swelling pressure. The different swelling pressure values of the studied microfacies due to the different percent and distribution of the clay minerals, where marlstone, marly limestone and mudstone microfacieses contained high percent of the clay minerals compared to dolomitic and detrital limestone microfacieses. The studied sedimentary rock microfacieses had retained percent ranging from 88.70 to $94.60 \%$. These microfacieses were described as medium to high durability after Gamble's classification. One sample (marlstone microfacies) had retained percent equal to $58 \%$ and was described as low durability. Because this microfacies contained high percent of the clay minerals.

4- The expansive sedimentary rock microfacieses of Durri Formation including mudstone, marlstone and marly limes tone microfacieses which represent the sub-grade of the road had been swollen (with swelling pressure values equal to 6.50 and $16.00 \mathrm{~kg} / \mathrm{cm} 2$ ) due to water coming from the damaged old water pipe which runs parallel to the road and that led to a heave of the road and the old water pipe. The heave of the old water pipe led to an increase of the damage and the amount of water co ming fro $m$ this pipe (Figure. 4 and 5). Consequently, that caused an increase of the swelling 
pressure and the heave which led to triple junction cracks. In addition, drying the saturated Pliocene sedimentary microfacieses (after reformation the individual damage at each zone) due to solar radiation led to a formation of large scale mud cracks having polygonal and randomly oriented forms. These cracks occurred on the asphalt layer and in the area around the road at the study area. The occurrence and the distribution of these cracks were depending on the distribution of the Pliocene sedimentary rocks, on the concentration and the distribution of the clay minerals (Illite and montmorillonite) of the studied Pliocene microfacieses, on the location of the water pipe damage and on the amount of the water coming from this damaged water pipe. The high temperature which characterized the arid region (Egyptian eastern desert) might be modified the illite mineral and increased its activity.

\subsection{Recommendations}

After an interpretation and an evaluation of the problem, the following points were recommended:

1- Constructing a new water pipe instead of the damaged old water pipe using flexible joints in order to support the possible new movements caused by the expansion.

2- Grouting and filling the cracks using cement.

3- Replacement of the expansive Pliocene sedimentary rock sub-grade using well graded sand and gravels and/or chemical stabilization of this sub-grade using lime to reduce the swelling pressure.

4-Monitoring system of the studied cracks using total station to evaluate the displacements of these cracks and to determine the relationship between cracks origin and recent tectonic movements at the studied area. An effective approach is to model the ground by using well-chosen discrete points located on the surface of the ground which, when situated correctly, accurately depict the characteristics of the ground. That means any movements of those points represent deformations of the object[23]. One of the most important aspects of any geodetic deformation monitoring network is the quality of monumentation. The survey monu ments can be installed at the stable edges of the cracks and the cracks center lines. A monu ment can be contained of a pin made of steel; it can be $1.5 \mathrm{~cm}$ in diameter and $10 \mathrm{~cm}$ in height. It can be centered in a concrete base with $30 \times 30 \mathrm{~cm}$. The survey targets can be centered on a steel pin.

5-Shallow seismic method was suggested to determine the real depth of these cracks.

\section{AKNOWLEDGEMENTS}

Greatly thanks to staff members of Qena faculty of engineering, in both South Valley University and Al-Azhar University, for offering the laboratories facility to conduct the geotechnical tests of this research.

\section{REFERENCES}

[1] EL-Shazly E.M., "Structural development of Egypt", 14th Ann. Mee., Geol. Soc. Egy pt, Abst., pp. 31-38, 1966.

[2] Youssef, "Structural pattern of Egypt and its interpretation", Am. Assoc. petrol. Geologist, Bull., vol.52, no.4, pp. 601-614, 1968.

[3] Tarabili E., "General outlines of the structures of the sedimentary formations in the centeral part of the Eastern Desert, Safaga-Quseir-Wadi Qena southern part", Bull., Inst. Desert Egy pt, vol.14, pp. 27-43, 1964.

[4] Abd-Alla A.H., Abu-Khadiah A.M. and Abd El-Razaik T.M., "New light on the geological structure of east Qena region, Upper Egypt", Proceeding of the VI colloquium on the geology of the African region, Athens, vol. 11, pp.767-778,1977

[5] El-Hakim B.E., "Study of aeromagnetic survey for Qena-Safaga area, Egypt ", 1978.

[6] Omran A.A., Riad S., Philobbos E.R. and Othman A.B., "Sedimentary basins and crustal thicknesses in Wadi Qena and the surrounding areas as interpreted from Bouguer anomalies. Egypt", J. Geol., vol.39,1, pp. 377-398, 1995b.

[7] EL-Kazazz Y.A., "Active faulting along Qena-Safaga road, Eastern Desert, Egypt", The first international conference on the geology of Africa. Assiut Univ., Egypt, vol. 2, pp. 385-404, 1999.

[8] Akawy A., "Structural geomorphology and neotectonics of the Qena-Saf aja district, Egypt", N. Jb. Geol. Paläont., Abh., 226, pp. 95-130, 2002.

[9] El-akraby A.M, "A contribution to the delineation of the geologic setting of the fracture area $(\mathrm{km} \mathrm{19-31)}$ along Qena-Safaga road, using geoelectrical studies", Ain Shams science Bulletin, vol. 38, 2002.

[10] Mohamed M.M. and Abdel-Gabar M., "Soil radon survey for tracing active fault: a case study along Qena-Safaga road, Eastern Desert, Egypt", Radiation Measurements, vol.37, pp. 211-216, 2003.

[11] Akawy A. and Kamal EL-Din G., "Structural Middle Eocene to Recent tectonics in the Qena area, Upper Egypt", N. Jb. Geol. Paläont., Abh., 240, pp. 19-51, 2006.

[12] Badawy A., Abdel-Monem S.M., Sakr K. and Ali Sh.M., "Seismicity and kinematic evolution of middle Egypt", Journal of Geodynamics, vol. 42, pp. 28-37, 2006.

[13] Azab M.A., "Assessment and management of natural hazards and disasters along Qena-Safaja road, Central Eastern Desert, Egypt", Egyptian Journal of Remote Sensing \& Space Science, vol. 12, pp. 55-70, 2009.

[14] Basher A.A., "Application of geophy sical techniques at new Qena city, Qena, Egypt", Master work thesis, South Valley University, Egypt, 2003.

[15] Wüst R.A.J. and McLane J., "Rock deterioration in the Royal Tomb of Seti I, Valley of the Kings, Luxor, Egypt", Engineering Geology, vol.58, pp. 163-190, 2000.

[16] Mahrous A.M., Tantawi M.M. and Hassan E., "Evaluation of the engineering properties of some Egyptian limestones as 
construction materials for highway pavements", Construction and Building Materials, vol.24, pp. 2598-2603, 2010.

[17] Issawi B., Hinnawi M., Francis M. and Mazhar A., "The phanerozoic geology of Egypt, a geodynamic approach", Geol. Surv. Egy pt, special publication no.76, 462p, 1999.

[18] Tensor Technical Note, TTN, "Chemical and mechanical stabilization of subgrades and flexible pavement sections", TTN, BR10, July 1998.

[19] Conoco, Inc., "Stratigraphic lexicon and explanatory notes to the geological map of Egypt, 1: 500000", the Egyptian petroleum Co-operation, Cairo, Egy pt, 1986.

[20] DIN-Taschenbuch 113, Erkundung des Baugrunds, "Einaxialer Druckversuch", DIN 18 136, DIN e.V., Wiesbaden, S. pp.372-375, 1998.

[21] Egy ptian code, "Egy ptian code of soil mechanics, foundations carrying out and designation", part 2, laboratory tests, six edition, 314p, 2001.

[22] Frankline j.A. and Chandra R., "The slake durability test. Int. Rock mechanics", Min. Sci. vol.9, pp. 325-341, 1972.

[23] Reitere A., Lehmann M., Fabiankowitsh J. and Kahmen H., "Quality control for building industry by means of a new optical 3D-measurment and analysis system", Technical report, Istitute of Geodesy and Geophysics, Vienna University of Technology, Gusshausstr, Vienna, Austria, 2007.

[24] Abd-El Razik T.M. and Razvaliaev A.V., "On the original of the Nile valley between Idfu and Qena, Egypt", J. Geol., vol.16, no.2, pp. 235-245, 1972.
[25] Ampera B. and Aydogmust T., "Recent experiences with cement and lime-stabilization of local typical poor cohesive soil", Geotechnik-kolloquium Freiberg, March 11, Heft 2005-2, pp.121-144, 2005.

[26] Badry M.M., "Geological and geotechnical studies on some types of sedimentary rocks in Egypt", Master work thesis, Faculty of science (Qena), South Valley University, Egypt, 2004.

[27] Bowles J., "Engineering properties of soil and their measurements", McGraw-Hill Boston, 4th edition, 1992.

[28] Conoco, Inc., "Geological Map of Egypt, 1: 500000-NG36NW-(ASYUIT)", the Egyptian petroleum Co-operation, Cairo, Egypt, 1987.

[29] Gamble J.C., "Durability-plasticity classification of shales and other argillaceous rocks", Ph.D. thesis, University of Illionois, 1971.

[30] Ismaiel H.A.H., "Treatment and Improvement of the geotechnical properties of different soft fine-grained soils using chemical stabilization", Ph.D. thesis, Mathematisch-Naturwissenschaftlich-Technischen Fakultät der Martin-Luther-Universität Halle-Wittenberg, Germany. Shaker verlag, ISBN-10:3-8322-5508-7, 2006.

[31] Ito M. and Azam S., "Determination of swelling and shrinkage properties of undisturbed expansive soils", Geotech. Geol Eng, vol.28, pp. 413-422, 2012.

[32] Omran A.A., Philobbos E.R., Riad S. and Othman A.B., "Subsurface structures and their surface reflection in Wadi Qena and the surrounding area", Egy pt J. Geol., vol. 39, no.1, pp.313-338, 1995a. 